\title{
Krzysztof Bosak's political views: targeting enemies in anti-democratic political thinking ${ }^{1}$
}

\begin{abstract}
This article aims to place the views of Krzysztof Bosak, the Confederation's candidate in the 2020 presidential elections, in the multifaceted typological frameworks of political thought. The analyzes show that Bosak's political views are primarily fundamentalist. However, classifying non-heteronormative people as objective enemies is indicative of totalitarian political gnosis. Bosak's views cannot be classified as belonging to the epigonic fascism cultivating interwar patterns, regardless of the type of national variation. Nevertheless, it is possible to classify them as glamor fascism. This type of fascism is velvety on the outside, but in fact, belonging to an offensive rather than defensive fundamentalism with significant elements of totalitarian political gnosis. In addition, it most often uses the imaginary concept of the nation as a post-ethnic community unpolluted by foreign elements. The analysis of Krzysztof Bosak's views may be useful for subsequent analyzes of the specific manifestations of quasi-militant democracy in terms of targeting enemies in anti-democratic political thinking.
\end{abstract}

Key words: glamor fascism; quasi-militant democracy; fundamentalism; totalitarian political gnosis

\section{Introduction}

tudying the political views of active politicians is always burdened with a great deal of uncertainty as to the nature of opinions. To what extent are they an expression of professed views, and to what extent do they appear due to the need to win the sympathy of potential voters? However, if we are dealing with a set of relatively uniformly distributed views, we can speak of their consistency resulting from the ideas of a given politician. It is also the case with Krzysztof Bosak, who throughout his adult life, regardless of the role of a politician or journalist, has been maintaining relatively unchanging views. This article aims to place the opinions of Krzysztof Bosak, the Confederation's (Polish: Konfederacja) candidate in the 2020 presidential elections in the multifaceted typological frameworks of political thought.

To address this objective, the study draws upon the method of source analysis. Primary sources were used to analyze Bosak's political views. The corpus of sources included texts he authored or co-authored. It was also necessary to use secondary sources, primarily press materials. This type of source and research field meant that it was essential to use the technique of content analysis. The research tool was a set of questions that allowed a researcher to obtain answers regarding the place of Bosak's political views in typological frameworks of political thought.

${ }^{1}$ This research paper is a result of the research project Contentious Politics and Neo-Militant Democracy. It was financially supported by the National Science Centre, Poland [grant number 2018/31/B/ HS5/01410]. 


\section{The Typologies of Political Thought}

Following David McLellan (1999), ideologies must be treated as extremely difficult to define, mainly due to the extraordinary diversity of colloquial approaches to this concept and the richness of scientific literature on this subject. The very word ideology was coined as early as during the French Revolution when Antoine Destutt de Tracy understood it as a science of ideas. He believed that it was possible to objectively and rationally discover the origins of ideas (Kennedy, 1979). From that moment on, the word ideology appears in many texts in all possible contexts and meanings. Among the most critical approaches, it is worth mentioning those that have become the most popular, thanks to pointing to the social functions of ideology. No wonder then that the concepts of the ideology of Karl Marx, Antonio Gramsci, or Herbert Marcuse were very well described in the literature on the subject (Eagleton, 2014; Leopold, 2013; Cohen, 1969; Mouffe, 2014). Equally important, however, are Karl Mannheim's attempts to reflect on the phenomenon of ideology. They very precisely distinguish Weltanschauung from ideology (Mannheim, 2013; Kumar, 2006).

Since the 1960s, ideology has been most often spoken of in an objective approach, treating it instead as an analytical category rather than allowing for the criticism of reality and designing a new one. Hence, the approaches to ideology created from that moment cease to have (though not wholly) such a characteristic of the previous ones as being entangled in the current political struggle. It is, therefore, worth paying attention to, for example, Martin Seliger's approach to ideology as a set of ideas that justify and account for the undertaken political actions (Seliger, 1979; 2019).

Following the same mindset, I propose to understand ideology as a set of hierarchically ordered values. The most important of them are treated axiomatically. In this case, we recognize the ideology by the existence of a hierarchy of values. There are one (sometimes two, less often three) values that are treated as axiomatic. The remaining values are at lower levels of importance and, simultaneously, of the hierarchy of subordination. In such an approach, a large area of political thought remains beyond the semantic scope of ideology.

In order to create typologies covering the entire field of political thought, it is worth transforming the typology of social communication. The model of three ways of communication between people (scientific, based on derivation, and communicative) presented by Vilfredo Pareto, based on two criteria - knowledge and the need for social bonds, shows that each of these three ways is about a different kind of human needs. In the first way of thinking - scientific, it is a model of truth that provides a sense of certainty and durability. The most common is the second method of communication based on derivations, i.e., the justification of residues - values that are constant and important for people. Derivations are used to present the residues so that it is possible to realize them while maintaining social bonds. This way of communicating produces mythical thinking that satisfies the need for security, individual and collective identity. Thinking of the third type, the communicative one serves only to create social bonds and thus meets the need of belonging (Bäcker, 2011).

In the first and third cases (scientific and communicative thinking), it is possible to create antinomic types. For scientific thought, this would be a quasi-scientific style, that 
is, taking the form of a scientific argument without using scientific research methods, with a simultaneous tendency to falsify the final results. Quasi-scientific thinking can be partially comparable to paranoia if only for its tendency to collect details to confirm a predetermined assumption at all costs. The antinomy of communicative thinking is vegetative, the most crucial goal of satisfying one's own life needs directly. There is no tendency to maintain social bonds in this case.

Mythical thinking in the form of a set of more or less ordered epiphenomena can manifest itself in three general ways: in the form of religion, ideology, or tribal thinking. The tribal mindset is one in which there is a very sharp distinction between "we" and "they." The type of tribal thinking disappears with the disintegration of traditional social structures. Paradoxically, on the margins of mass societies transforms into a much more primitive form, which can be called a type of post-tribal thinking devoid of morals, unwritten codes of conduct, and rich symbolism. What remains is the awareness of the distinctiveness of one's own place of residence and the ignorant treatment of all foreign matters. The post-tribal consciousness is, therefore, more atavistic and primal than the tribal one. No wonder it is usually tightly coupled with vegetative consciousness.

Fundamentalism is a specific transformation of usually religious thinking. While an evident hierarchy of values is typical for every religion and ideology, fundamentalism is more tribal. The primary division for fundamentalists comes from the dual distinction between "we" and "they." "We" are the community of, for example, the faithful observing the rules of faith and fully submitting to them, and "they" is constituted by those who do not. Fundamentalism is a typical form of counter-acculturation. It is a reaction to the feeling of threat from the dominant culture, modernization pressures, especially felt by people firmly rooted in tradition, usually religious. Characteristic features of fundamentalist thinking are, therefore, a very sharp (black and white) distinction between "we" and "they" and the figure of a besieged fortress in which "we" must defend ourselves against enemies.

After an appropriate transformation of essential elements of its structure, fundamentalist thinking can be transformed into totalitarian political gnosis. Gnosis, e.g., Manichean, but also totalitarian, is a hybrid resulting from an attempt to synthesize religion or ideology with the model of truth. However, due to the non-critical, monopolizing approach to this model, this way of thinking treats science only as a form, and thus, in essence, it is not used. Still, its antithesis, quasi-science, provides an intellectual framework. The defining features of totalitarian political gnosis include the imagined subject, the objective enemy, and the apokatastasis. In the 20th century, the latter was most often treated as secular salvation ("here and now") possible to be realized thanks to the efforts of the imagined subject, which, however, is hindered due to the actions of objective enemies.

All of the above types of thinking can be placed on a continuum between the two extreme points of two logics: analytical and emanatistic. Scientific thinking is closest to the analytical logic, while near the emanatistic logic is totalitarian political gnosis and, to a large extent, manifestations of intellectual counter-acculturation. The word "intellectual" is understood here as in any way an ordered mental construct. Thus, we deal with the following series of thinking types on the continuum, ranging from emanatistic to analytical logic: totalitarian political gnosis, fundamentalism, vegetative and post-tribal 
thinking, tribal thinking, universal religions, and ideologies, scientific thinking (Bäcker, 2003; 2011).

The above typology covers all manifestations of political thought. However, it is necessary to remember that all the mentioned earlier categories of political thought must be treated as ideal types. Concrete manifestations of political thought are more or less distant from a given ideal type. They are located between two or more ideal types on the continuum between the latter.

\section{The Place of Fascism in Typologies of Political Thought}

Fascism as a political movement arose at the beginning in Italy. After the March on Rome (Italian: Marcia su Roma) organized by Benito Mussolini, it became a compulsory way of thinking for the political elites and a determinant of the organization of state and social life. Hungary defined its rule as fascist from 1932 onwards. Next year, the power in Germany was taken over by the National Socialists under the leadership of Adolf Hitler, who initially treated the Italian example as the worthiest to follow. From 1933, the Iron Guard, which became one of the ruling parties in Romania, increased its importance.

Stanley G. Payne, in his history of fascism, treats Lithuania, Yugoslavia, the Sanation Poland, and post-war Greece as para-fascist states borrowing many elements from Italian fascism (Payne, 1996, p. 145). Fascist parties existed in the interwar period in all other European countries and, for example, in Latin America. The exception was the USSR, although fascist and similar organizations operated in several circles of the Russian emigration. In interwar Poland, several fascist organizations and radical national organizations can be treated as fascist or similar. Post-fascist movements have existed in many European countries, including contemporary Russia (Bäcker, 2001).

The above enumeration concerns parties and movements that admitted to fascism or were inspired by fascist characters or slogans. Much more important in identifying fascist views, or similar to them, is the reconstruction of the thinking patterns typical of this political trend.

Roger Eatwell lists four aspects relevant to fascism: (1) plan to change human nature and create a better society; (2) nation or race as forces organizing evolution and progress; (3) criticism of capitalism, liberalism, and socialism as systems that break up or weaken the community; and (4) instilling human minds with fascist values through media and propaganda (Eatwell, 1996; 2013). This type of description made by an outstanding American historian shows that fascism belongs to totalitarian political gnosis. However, careful analysis of fascism calls for a slightly different classification.

In 1932, Benito Mussolini (but some researchers also point to Giovanni Gentili working as a ghostwriter) wrote a text describing the doctrine of fascism. It contains a negative program primarily. Fascism is hostile to democracy, liberalism, and socialism. However, it does not apply to Bolshevism, the solutions from which Italian fascism drew much. The positive agenda is quite simple. First, it is statolatry and therefore treating the state as the most important value. In addition, the cult of power and strength should be mentioned. Instead of a free market, there is to be a corporate economic system harmoniously reconciling the interests of all people (Mussolini, 1992, reprint of 1932). 
This way of thinking is characterized by a very sharp, even black and white, juxtaposition of "we" and "they." In addition, it draws upon emotional thinking. "They" are evil, while "we" are good. Thus, hatred and love must be treated as inseparable from the evaluation of the political scene. Fascism, as understood by Mussolini, can be treated as belonging to fundamentalist thinking.

Post-war and contemporary fascism - multifaceted and taking shape in many countries - can be placed between mild fundamentalism and totalitarian political gnosis. To a large extent, it is of a glamor type - gentle, almost velvety, intended to be not only acceptable but also highly accessible (see Bäcker, 2017). Due to the variety of fascist variants, I treat these manifestations of political thought as lying between ideal types of fundamentalism and totalitarian political gnosis, with the particular intensity of "hard," most often offensive fundamentalism. It is the kind of fundamentalism that does not believe that one should defend oneself against the often imagined enemy, but the latter should be attacked (see Bäcker, 2001).

\section{Views of Krzysztof Bosak as an Activist of the All-Polish Youth, LPR, and Confederation}

At the age of eighteen, Krzysztof Bosak (born in 1982) joined the All-Polish Youth (Polish: Młodziez Wszechpolska) in Wrocław, and from 2001 he was the plenipotentiary, and in the years 2003-2004 the president of the district in the Lubuskie Province. From February 2004 to April 2005, he was the secretary of the mainboard and then the press spokesman until November 2005. From November 2005 to December 2006, he was the national president of the All-Polish Youth.

From 2001, he belonged to the League of Polish Families (Polish: Liga Polskich Rodzin, LPR). From this list, in 2005, he obtained a parliamentary seat. In 2008, he resigned from membership in the LPR and withdrew from political activity, focusing mainly on journalistic activity. From 2012, he became involved in the activities of the National Movement (Polish: Ruch Narodowy). However, Bosak gained political significance only from 2019, becoming one of the leaders of a vast coalition under the name: Confederation KORWiN Braun Liroy Nationalists (Polish: Konfederacja KORWiN Braun Liroy Narodowcy). In the same year, he also became one of the leaders of the Confederacy Freedom and Independence party (Polish: Konfederacja Wolność i Niepodległość). In 2020, he was a candidate in the presidential elections (both in the ghost elections that were not held on May 10 and in the first round of presidential elections on June 28).

Przemysław Witkowski writes about personal and journalistic relationships between activists of the All-Polish Youth and neo-fascist organizations, i.e., the magazine "Szturm" (Witkowski, 2019). However, treating the views of the individuals concerned as unambiguous due to the publication of texts in the same journal is not convincing.

It is much more essential to analyze the structures of thinking. In the case of Krzysztof Bosak, it is more complex, mainly due to the way of presenting his views adopted for over a dozen years. Characteristic for Krzysztof Bosak is the way of showing his ideas presented in the article: Bankructwo mitów i rekonstrukcja ruchu (English: Bankruptcy of Myths and Movement Reconstruction) (Bosak, 2008). Konrad Jajecznik very well pre- 
sented it by stating what follows: "Krzysztof Bosak, who does not belong to the editorial office, joins the postulate of caution. He recommends abandoning aggressive rhetoric, which exposes users to further discredit as alleged 'fascists,' which - despite its dishonesty - effectively undermines the credibility of the attacked in the eyes of less informed citizens. Searching for the possibility of modernizing nationalism, he dissociates himself from participating in the auction of radicalism, which effectively perpetuates isolation. He points out that gaining a significant political position does not require controversial slogans, but the creation of a 'third discourse' on the right, distinguishing nationalists from conservatives and liberals" (Jajecznik, 2013, p. 368).

Krzysztof Bosak will abide by this directive concerning the way of presenting his thinking to a great extent. The only exceptions are the quite frequent statements by Krzysztof Bosak about non-heteronormative people. In 2005, he stated unequivocally: "Pederasty is not normal, it is a disorder" (Parady nienormalności, 2005). Even more radical was Bosak's original text Policja broniła pedałów (English: Police Defended Fagots), also from 2005. For example, he wrote: "On Saturday, June 11 in Warsaw, we could observe the most glaring manifestation of the homo-revolution that the faggy international is trying to accomplish" (Bosak, 2005). Non-heteronormative people are treated as enemies to be excluded from the national community.

In the text mentioned above of June 19, 2005, Krzysztof Bosak states very clearly: "Poland will restore normality to Europe. This is where the impulse to cleanse Europe will come from. We will be an embankment against the onslaught of deviation" (Parady nienormalności, 2005). On the one hand, there are enemies, and on the other - the Polish nation, which not only has to stand up for the truth but will also be able to free Europe from "deviation." The figures of the enemy, the saving subject ("Polish nation"), and the ultimate goal were clearly articulated. This way of thinking can be treated as a manifestation of totalitarian political gnosis.

Jewish issues are raised much less frequently. In 2018, Bosak wrote: "During the PiS rule, our diplomacy has already issued over 7,000 passports in Israel, which is the fastest pace in 15 years! Have you ever heard about it on TVP or at meetings with PiS politicians?" (Ogromne tempo, 2018). Jews who obtain Polish citizenship and do not speak Polish are treated in this text as not belonging to the Polish nation. Bosak treats this type of inclusion policy as a threat to the functioning of the Polish nation.

Krzysztof Bosak spoke out many times in public, denying any ties with fascism. One of the longer statements was recorded in 2006: "This party with a swastika in the background and Nazi greetings was not our party, and it is absurd to attribute fascist views to us. We make fun on nationalist internet forums that we cannot make a serious brawl. That we are good boys. Our organization consists of several thousand people who really do something good. They are ordinary young people, not some dumb thugs. The media want to trample us into the ground, but they strengthen us with these attacks. They treat us like a pile of idiots. And as one of the columnists stated, perhaps we are already the last group that treats patriotism seriously" (Legiony Romana, 2006).

He repeats more or less the same thing in 2020: "Fascism is a collection of utopias from the 1930s, completely outdated in today's world and alien to our national thought. It is inconsistent with conservatism and Catholicism" (Grochal, Śmigaj, 2020). However, a careful interpretation of the above refutations is necessary. Bosak denies the will to 
use physical violence against his political enemies and treats (many times) interwar fascism as an obsolete creation. Therefore, he cannot be treated as a supporter of epigonic fascism, which directly accepts the views of, for example, Mussolini. However, nowhere do we find a rejection of the thoughts most important to broadly understood fascism, i.e., one that falls between fundamentalism and totalitarian political gnosis, with a solid rejection of the values typical of an open society, the rule of law, and democratic pluralism.

It is worth quoting the entry on the understanding of the rule of law as a confirmation. Bosak wrote on Twitter in 2019 that "The rule of law with the judiciary exercised by the Gentiles is a complete mistake. If the constitutional court is to have the power to change the norms of social life, it is only on the condition that traditional Christians staff it. Otherwise, it introduces chaos or directly supports evil" (Bosak, 2019).

Bosak undoubtedly does not profess National Socialist views. The most important value for him is the ethnic and cultural nation determined by Catholic rituals. However, it is an exclusive concept of the nation. The latter does not contain those who do not follow the national tradition, including the non-heteronormative. All those external and internal forces that do not accept this vision of the nation are the enemy. It is the thinking typical of fundamentalism and, in the case of non-heteronormative people, specific of totalitarian political gnosis.

\section{Presidential Program of Krzysztof Bosak}

Krzysztof Bosak's presidential program was entitled "Nowy porządek. Tezy konstytucyjne" (English: "New Order. Constitutional Theses" (Bosak, 2020). This program is common to all groupings that are part of the Confederation, and thus it is a kind of compromise. It expresses views on which there is convergence and not those that are characteristic, for example, only for Bosak. However, it is worth pointing to some of its important components.

First, it assumes a substantial strengthening of the prime minister's power, who has the right to veto bills passed by the Sejm that consists of half of today's deputies. It is an apparent manifestation of the desire to gain the advantage of the executive over the legislature.

Second, anti-European Union sentiment is visible. The provision that the constitution is to be treated as a legal act of the highest order (as it is now) should be appropriately interpreted. It means that European Union (EU) law is not to affect Polish legislation. Accordingly, it is evidenced by the following entry: "The principle should also be introduced that Polish courts are not bound by the interpretation of law created by international judicial institutions" (Bosak, 2020, p. 17). It means that EU law is not to be binding in Poland. It is, in fact, a program of exit from the EU, although it was not stated explicitly.

Third, it aims to eliminate even the possibility of any legal regulation of the situation not only of sexual minorities but also of civil unions. We read on p. 20: "For many years, we have been observing in Poland and many other countries, attempts to undermine the fundamental civilizational role of marriage and family. The Polish Constitution should neutralize these attempts by unequivocally excluding the legal privilege or recognition of any other relationships - partnerships, cohabitation, homosexuals, etc." (Bosak, 2020, p. 20). The last sentence indicates that the most critical issue is not protecting the family but the political and social exclusion of unmarried and not single people. 
Fourth, Bosak devotes a lot of space to the fight against gender: "The Polish legal order should respect the biological determinant of gender, which is the human genetic structure. At conception, a person's sex is determined permanently. The Polish legal system should refer to the objective and unchanging truth (sic! - RB) about gender resulting from this fact. Experiencing sexuality or the shape of sexual characteristics may be subject to disturbances and manipulations. However, this cannot affect the gender in marital status records, nor can it be a basis for gender relativization or normalization of transsexualism. It cannot be allowed to enter into homosexual relationships based on the changed gender in the marital status records. The state and the law must be based on the natural social order, resulting from the different and complementary nature of men and women, and reject the erroneous and socially harmful paradigm of 'gender"' (Bosak, 2020 , p. 21). The fight against the "gender paradigm" is a total refutation of cultural and gender differences. Entering this path makes it easy to follow the following steps in two non-exclusive ways - refuting all otherness and striving for the progressive exclusion up to evaporation of people belonging to the "other world."

Fifth and most importantly, the whole essence of the changes to the constitution rests on the concept of the nation. Thus, we read: "the Polish nation, shaped in the course of a thousand-year history [...] the state should create conditions for the preservation of the national identity, the development of its elites and the strengthening of political and economic independence [...] the nation is our natural community, guaranteeing the continuity of culture" (Bosak, 2020, p. 7). It is the concept of a genetic nation based on traditional cultural patterns. If, in addition, the postulate of virtually banning citizenship is taken into account, then we are dealing with the concept of a nation that is closed to anyone who is not "ours."

Each pre-election political program is written in such a way as to attract as many voters as possible, voters whose views are at least slightly similar to those held by its authors. Extreme theses and genuine intentions are avoided. Nevertheless, it is possible to identify the essential structures of thinking they contain. First, it is the concept of the enemy. All external institutions, including the EU, are the enemy. For instance, it is she or he who wants to deprive "us" of our sovereignty. The enemies are also "strangers" living inside "us," i.e., non-heteronormative people, immigrants, people in partnerships, or cohabitation. Anyone who lives differently than "we" cannot belong to "us" and therefore to "our nation." Second, the striving for a strong state authority is visible, in which the executive is mainly stable and has significant power competencies. It is a concept of a closed, exclusive, and anti-dialogic society. Personal opinions are treated as truths beyond any doubt.

In this program, the black and white pattern of thinking is cultural, not political or economic. However, it is necessary to use the tools of violence that the state can use for its implementation. The exclusion from the national community of non-heteronormative people is comparable to the exclusion from the German nation of those of Jewish origin up to the third generation back, as specified in the Nuremberg Laws.

\section{Conclusions}

To sum up, Bosak's political views did not evolve too much. It is worth paying attention to the increasing ability to present his own opinions precisely and in a "velvet" way. 
The ability to collect and reliably present facts in the field of economic matters deserves recognition.

An extremely significant achievement before the 2020 presidential election was developing a joint program by the diverse political circles making up the Confederation of Freedom and Independence. It is also worth noting that the name refers directly to the national ideas of the post-war anti-communist underground. It is a clear sign of the domination of the national ideas within this politically diverse grouping.

Bosak's views are based on a semantic resource characteristic of national ideology. However, this is not typical of ideological political thinking. In terms of culture and the functioning of the state, understanding the nation, "the others," this political thinking is a way of understanding the world that is typical of fundamentalism. In the case of non-heteronormative people, it is not only striving for their total exclusion and treating them as enemies of the sacralized Polish nation with messianic goals. It is the way of thinking typical of totalitarian political gnosis.

The analysis of Bosak's views may be helpful to analyze specific manifestations of quasi-militant democracy in terms of targeting enemies in anti-democratic political thinking. Quasi-militant democracy is an antinomic concept of neo-militant democracy. Democracy is not defended, but under the cover of democratic slogans, efforts are made to deprive the political nation of sovereignty (Rak, 2020).

\section{Bibliography}

Bäcker R. (2001), Rosyjski faszyzm, "Slavia Orientalis", vol. 50, no. 4, pp. 615-629.

Bäcker R. (2003), Nie-tradycyjna typologia myśli politycznej, in: Zrozumieć politykę. Główne problemy teorii polityki i współczesnej myśli politycznej, eds. R. Bäcker, J. Marszałek-Kawa, J. Modrzyńska, Toruń, pp. 101-112.

Bäcker R. (2011), Nietradycyjna teoria polityki, Wydawnictwo Naukowe Uniwersytetu Mikołaja Kopernika.

Bäcker R. (2017), Totalitaryzm w cywilizacji informatycznej, "Studia nad autorytaryzmem i totalitaryzmem", vol. 39, no. 1, pp. 9-18.

Bosak K. (2005), Policja broniła pedałów, “Myśl Polska”, no. 18.

Bosak K. (2008), Bankructwo mitów i rekonstrukcja ruchu, "Polityka Narodowa", no. 2-3.

Bosak K. (2019), Twitter, 3 stycznia 2019, 15.07.2021.

Bosak K. (2020), Nowy porzadek. Tezy konstytucyjne, https://bosak2020.pl/wp-content/uploads/Bosak2020_NowyPorzadek.pdf, 15.07.2021.

Cohen J. (1969), The philosophy of Marcuse, "New Left Review”, no. 57, pp. 35-52.

Eagleton T. (2014), Ideology, Routledge.

Eatwell R. (1996), Fascism: A History, Allen Lane.

Eatwell R. (2013), Fascism, in: The Oxford Handbook of Political Ideologies, eds. M. Freeden, M. Stears, Oxford University Press.

Grochal R., Śmigaj M. (2020), Krzysztof Bosak narobit dtugów, które zostały spłacone pieniędzmi ze zbiórki dla chorej na raka, „Newsweek”, 5.07.2020, https://www.newsweek.pl/polska/krzysztof-bosak-kim-jest-krzysztof-bosak/esj158z, 16.07.2021.

Jajecznik K. (2013), Próba integracji młodego pokolenia nacjonalistów wokót pisma „Polityka Narodowa" w latach 2008-2012, in: Prasa Narodowej demokracji (T. 4, prasa lokalna, regionalna, środowiskowa), eds. E. Maj, A. Dawidowicz, Wydawnictwo UMCS. 
Kennedy E. (1979), "Ideology" from Destutt De Tracy to Marx, "Journal of the History of Ideas", vol. 40, no. 3, pp. 353-368.

Kumar K. (2006), Ideology and Sociology: Reflections on Karl Mannheim's Ideology and Utopia, "Journal of Political Ideologies", vol. 11, no. 2, pp. 169-181.

Legiony Romana, Newsweek.pl, 3 grudnia 2006.

Leopold D. (2013), Marxism and ideology: From Marx to Althusser, in: The Oxford Handbook of Political Ideologies, eds. M. Freeden, M. Stears, Oxford University Press.

Mannheim K. (2013), Ideology and utopia, Routledge.

McLellan D. (1999), Then and now: Marx and Marxism, "Political Studies", vol. 47, no. 5, pp. 955-966.

Mouffe C. (2014), Hegemony and ideology in Gramsci, in: Gramsci and Marxist theory, Routledge, pp. 168-204.

Mussolini B. (1992), Doktryna faszyzmu, Merkuriusz Polski.

Ogromne tempo wydawania polskich paszportów w Izraelu. Zaledwie co 20 nowy obywatel mówi w naszym języku, stefczyk.info, 22 czerwca 2018, 15.07.2021.

Parady nienormalności, Newsweek.pl, 19 czerwca 2005, 15.07.2021.

Payne S. G. (1996), A history of fascism, 1914-1945, University of Wisconsin Press.

Rak J. (2020), Quasi-Militant Democracy as a New Form of Sacred in Poland During the Corona Crisis, "Journal for the Study of Religions and Ideologies", vol. 19, no. 57, pp. 111-128.

Seliger M. (1979), The Marxist conception of ideology: A critical essay, Cambridge University Press.

Seliger M. (2019), Ideology and politics, Routledge, 1st edition 1976.

Witkowski P. 17 marca 2019, Duce, prowadź do Szturmu! Liderzy Ruchu Narodowego publikuja w faszystowskim piśmie, https://oko.press/duce-prowadz-do-szturmu-liderzy-ruchu-narodowegopublikuja-w-faszystowskimpismie/?fbclid=IwAR2avx4J0LFAtkXcdyS3NbB08dZJS_yeJRmi9R_3kQFbeS3Q11-IusrqF8Q, 15.07.2021.

\section{Poglądy polityczne Krzysztofa Bosaka: typowanie wrogów $w$ antydemokratycznym myśleniu politycznym}

\section{Streszczenie}

Celem artykułu jest umieszczenie poglądów Krzysztofa Bosaka - kandydata Konfederacji w wyborach prezydenckich 2020 roku w wielopłaszczyznowych siatkach typologii myśli politycznej. Z przeprowadzonych analiz wynika, że poglądy polityczne Bosaka mają charakter przede wszystkim fundamentalistyczny. Natomiast widoczne są w przypadku stosunku do osób nieheteronormatywnych (klasyfikowanych jako wrogowie obiektywni) elementy totalitarnej gnozy politycznej. Poglądy Bosaka nie mogą być zakwalifikowane jako należące do epigońskiego faszyzmu kultywującego międzywojenne wzory i to niezależnie od rodzaju narodowej mutacji. Możliwe jest natomiast zaklasyfikowanie ich jako glamur faszyzm. Jest to faszyzm na zewnątrz aksamitny, w istocie swojej raczej należący do ofensywnego niż obronnego fundamentalizmu ze znaczącymi elementami totalitarnej gnozy politycznej. Ten rodzaj faszyzmu najczęściej posługuje się wyobrażonym pojęciem narodu jako niezanieczyszczonej obcymi elementami wspólnoty post-etnicznej. Badanie poglądów Krzysztofa Bosaka może być przydatne dla następnych analiz konkretnych przypadków przejawiania się quasi-demokracji opancerzonej szczególnie w zakresie typowania wrogów w antydemokratycznym myśleniu politycznym.

Słowa kluczowe: glamur faszyzm, quasi-demokracja opancerzona, fundamentalizm, totalitarna gnoza polityczna 